\title{
Choice of common bean parents based on combining ability estimates
}

\author{
Cristina de Fátima Machado, João Bosco dos Santos, Glauber Henrique de Sousa Nunes \\ and Magno Antonio Patto Ramalho \\ Departamento de Biologia, Universidade Federal de Lavras, Lavras, MG, Brazil.
}

\begin{abstract}
The obtention of genetically improved cultivars is the main objective of breeding programs, whose efficiency is increased by a careful choice of parents. Based on both general (GCA) and specific (SCA) combining abilities for grain yield, the purpose of this research was to choose the most promising populations of common beans, for line selection. GCA and SCA were measured by means of a complete diallel without reciprocals, using twelve cultivars/lines. Parents and corresponding $\mathrm{F}_{2}$ segregating populations were evaluated for grain yield by a $9 \times 9$ triple square lattice design. It was found that the segregating populations differed in grain yield, with predominant SCA effects, but with significant GCA effects as well. Among the populations derived from parents with positive GCA values, Aporé $\times$ Cl-128, Cl-128 x Pérola, PF-9029975 x Ouro Negro, and Cl-128 x Ouro Negro also showed positive SCA values and high grain yields, therefore being the most promising populations for grain yield improvement. The highest values of specific combining ability were observed in populations H-4-7 x ESAL 693, Cl-128 x Pérola, and A-285 Rudá x IAC Carioca Aruã, which must be the most segregating ones. Hybrid combinations with a high SCA deriving from at least one parent with high GCA were: Pérola $\times \mathrm{Cl}-128$ and Ouro Negro $\times$ Pérola. Although line ESAL 693 presented the lowest GCA value, one of its derived populations, ESAL $693 \times \mathrm{H}-4-7$, had the highest SCA and heterosis values. The high correlation between heterosis and SCA indicates that heterosis can be useful when SCA is not available.
\end{abstract}

Key words: Phaseolus vulgaris, specific and general combining ability, diallel.

Received: March 5, 2002; accepted: April 26, 2002.

\section{Introduction}

Increase in yield potential of common bean (Phaseolus vulgaris) cultivars has been small, in spite of large variation of most traits, including grain yield. Therefore, the obtention of genetically improved cultivars is the main objective of breeding programs, which have their efficiency increased by a careful choice of parents. One of the most commonly used methodologies for choosing parents is diallel cross, which informs about the parents' potential when in hybrid combinations, and also about gene action involved in determining quantitative traits (Cruz and Vencovsky, 1989; Ramalho et al., 1993). Griffing's (1956) diallel analysis procedure is among the most useful ones, especially its method IV, which only considers the hybrid performance, and allows to estimate both exact SCA and GCA.

As GCA depends predominantly on additive effects of the genes, it informs about the potential of the segregating populations for selection of high grain yield lines

Send correspondence to João Bosco dos Santos, Departamento de Biologia, Universidade Federal de Lavras, 37200-000 Lavras, MG, Brazil. E-mail: jbsantos@ufla.br.
(Ramalho et al., 1993). It has been the parameter employed to choose promising segregating populations, which should have the highest averages. As for SCA, which depends predominantly on non-additive effects of the genes, it allows to identify populations which are potentially more useful to liberate variability in the segregating generations (Veiga et al., 1998).

The purpose of this research was to choose the most promising common bean populations for selection of lines, based on general and specific combining abilities for grain yield, and to verify the association between specific combining ability and heterosis.

\section{Material and Methods}

This study was carried out on the experimental field of the Biology Department of the Federal University of Lavras (UFLA), located in the southern region of the State of Minas Gerais, Brazil, at an altitude of $910 \mathrm{~m}, 21^{\circ} 45^{\prime} \mathrm{S}$ latitude, and $45^{\circ} 00^{\prime} \mathrm{W}$ longitude. The soil in the experimental area is classified as dystrophic dark red latosol, cerrado phase. 


\section{Material}

Cultivars and lines used are listed in Table I. They were crossed according to the complete diallel scheme without reciprocals (Griffing, 1956). The crosses were done as suggested by Ramalho et al. (1993).

\section{Experimental procedures}

Parents and $\mathrm{F}_{2}$ segregating populations were evaluated by means of a $9 \times 9$ triple lattice design. Each plot consisted of two two-meter-long rows, $50 \mathrm{~cm}$ apart, with 15 seeds sown per linear meter. Controls CII-244, CII-348, IAPAR-81, LH-9, Carioca, B1 and LH-11 were included. The equivalent of $400 \mathrm{~kg} / \mathrm{ha}$ of the formula 4-14-8 $\left(\mathrm{N}, \mathrm{P}_{2} \mathrm{O}_{5}\right.$ and $\mathrm{K}_{2} \mathrm{O}$, respectively) was used as a fertilizer during sowing, and $150 \mathrm{~kg} / \mathrm{ha}$ of ammonium sulfate were applied 20 days after emergence. The field was irrigated by aspersion when necessary. Grain yield was determined for each plot and expressed as $\mathrm{kg} / \mathrm{ha}$.

\section{Genetic and statistical analysis}

Grain yield of segregating populations, parents and controls was analyzed according to the statistical model $Y_{i j w}=u+t_{i}+r_{j}+b_{w(j)}+e_{i j w}$, where $Y_{i j w}$ is the grain yield of treatment "i" in block " $w$ " within replication " $\mathrm{j}$ "; $u$ is the general mean of the treatments; $t_{i}$ is the fixed effect of treatment $i(i=1, \ldots 81) ; r_{j}$ is the random effect of replication " $j$ " $(j=1, \ldots 3) ; b_{w(j)}$ is the random effect of block "w" within replication " $\mathrm{j}$ " $(w=1, \ldots 9)$, and $\mathrm{e}_{\mathrm{ijw}}$ is the error effect of the plot that received treatment "i", in block "w", within replication “ "j", and $\sim \mathrm{N}\left(0, \sigma^{2}\right)$.

The sum of squares of the segregating populations, estimated from the adjusted means of previous variance analysis, was decomposed in the diallel analysis, according to method IV (Griffing, 1956), using the model $\overline{\mathrm{Y}}_{\mathrm{ij}}=\mathrm{m}+\mathrm{g}_{\mathrm{i}}$ $+\mathrm{g}_{\mathrm{j}}+\mathrm{s}_{\mathrm{ij}}+\overline{\mathrm{e}}_{\mathrm{ij}}$, where $\overline{\mathrm{Y}}_{\mathrm{ij}}$ is the mean value of hybrid $\mathrm{ij}(\mathrm{i}$, $\mathrm{j}=1,2, \ldots \mathrm{p}, \mathrm{i}<\mathrm{j}) ; \mathrm{m}$ is the general mean of the segregating populations; $g_{i}$ and $g_{j}$ are the general combining ability effects of the $\mathrm{i}^{\text {th }}$ and $\mathrm{j}^{\text {th }}$ parents, respectively; $\mathrm{s}_{\mathrm{ij}}$ is the specific combining ability effect of the $\mathrm{ij}^{\text {th }}$ cross, and $\overline{\mathrm{e}}_{\mathrm{ij}}$ is the error associated with the $\mathrm{it}^{\text {th }}$ observation.

Since it was not possible to obtain four of the 66 hybrid combinations, the least square method (Vencovsky and Barriga, 1992) was used to estimate the parameters of the model, and Searle's (1976) parametric restriction $\sum_{i=1}^{12} n_{i} g_{i}=\phi\left(n_{i}\right.$ is the number of crosses involving each parent) to solve the generalized inverse matrix.

The variance estimate of the general combining ability was obtained using the diagonal of the augmented matrix $\left(\mathrm{X}^{\prime} \mathrm{X}\right)^{-1}$ multiplied by the mean square of the effective error of the variance analysis, divided by the number of data that originated the average.

Heterosis was estimated by the expression: $\hat{\mathrm{h}}_{\mathrm{ij}}(\%)=\frac{2 \bar{F}_{2}-\bar{P}_{i}-\bar{P}_{j}}{\bar{P}_{i}+\bar{P}_{j}}$, where $\hat{\mathrm{h}}_{\mathrm{ij}}$ is the average heterosis of the $\mathrm{F}_{2}$ population obtained from the cross of $\mathrm{i}$ and $\mathrm{j}$ parents, $\overline{\mathrm{F}}_{2}$ is the mean grain yield of the $\mathrm{F}_{2}$ population, and, $\overline{\mathrm{P}}_{\mathrm{i}}$ and $\overline{\mathrm{P}}_{j}$ are the corresponding means of parents $i$ and $j$, respectively.

The rank correlation between heterosis and SCA was estimated.

\section{Results and Discussion}

The variance analysis of grain yield indicated a significant genetic difference between treatments at the proba-

Table I - Origin, genealogy, growth habit, coat color and 100-seeds-weight of 12 common bean cultivars/lines.

\begin{tabular}{|c|c|c|c|c|c|}
\hline Cultivars & origin & Genealogy ${ }^{2 /}$ & Growth habit ${ }^{1 /}$ & Coat color & 100 -seeds weight $(\mathrm{g})$ \\
\hline 1-Aporé & CNPAF & $\begin{array}{l}\text { (Carioca/Mexico168)//(Cari- } \\
\text { oca/Bat76) }\end{array}$ & III & Beige with brown stripes & 27 \\
\hline $2-\mathrm{H}-4-7$ & UFLA & (EMGOPA 201 Ouro/Carioca) & III & Beige with brown stripes & 21 \\
\hline 3-PF -9029975 & CNPAF & (Carioca80/Rio Tibagi) & II & Beige with brown stripes & 17 \\
\hline $4-\mathrm{CI}-128$ & UFLA & Recurrent selection & III & Beige with brown stripes & 25 \\
\hline 5-Carioca - MG & UFLA & (Carioca 80/Rio Tibagi) & II & Beige with brown stripes & 18 \\
\hline 6-CI - 21 & UFLA & Recurrent selection & III & Beige with brown stripes & 22 \\
\hline 7-Carioca $300 \mathrm{~V}$ & UFLA & Selection in Carioca & III & Beige with brown stripes & 22 \\
\hline 8-Ouro Negro & CIAT & Introduction of Honduras & III & Black & 24 \\
\hline 9-A-285 Rudá & CIAT & (Carioca/Rio Tibagi) & II & Beige with brown stripes & 16 \\
\hline 10-ESAL 693 & UFLA & (Carioca TU/Line 3272) & I & Beige with brown stripes & 19 \\
\hline 11-Pérola & CNPAF & Selection in Aporé & II/III & Beige with brown stripes & 23 \\
\hline 12-IAC Carioca Aruã & IAC & (Cornell 49-242/AB-136) & II/III & Beige with brown stripes & 25 \\
\hline
\end{tabular}

2/: single cross; //: double cross. 
Table II - Variance analysis of grain yield ( $\mathrm{kg} / \mathrm{ha})$ of parents, controls and $\mathrm{F}_{2}$ populations

\begin{tabular}{lcc}
\hline Sources of variation & $\begin{array}{c}\text { Degree of } \\
\text { freedom }\end{array}$ & $\begin{array}{c}\text { Mean square } \\
\left(10^{-5}\right)^{\underline{1}}\end{array}$ \\
\hline Replication & 2 & 1.79 \\
Non-adjusted treatment & 80 & $8.76^{* *}$ \\
Adjusted treatment & 80 & $8.57^{* *}$ \\
Block/replication(adjusted) & 24 & 6.44 \\
Effective error & 136 & 4.37 \\
Random block error & 160 & 4.49 \\
Intrablock error & 136 & 4.15 \\
Total & 242 & - \\
Lattice efficiency & - & 102.81 \\
Coefficient of variation (\%) & - & 21.14 \\
Mean & - & 3126.22 \\
\hline
\end{tabular}

$1 / * *$ : significant at $1 \%$ level of probability in the $\mathrm{F}$ test.

bility level of $1 \%$ (Table II). The lattice showed little efficiency due to the reduced and uniform experimental area. Experimental precision, measured by the variation coefficient, was adequate, because it fell among the values usually obtained for this trait in common bean experiments (Ramalho et al., 1993 and Abreu, 1997).

The decomposition of the sum of squares of populations in the general (GCA) and specific (SCA) combining abilities is presented in Table III. For GCA, the mean square was significant at the $5 \%$ level of probability, whereas for SCA, it was significant at $1 \%$. According to these results, the genetic quadratic component of SCA is about four times higher than the component of GCA, and both can be approximately estimated from the mean squares (Table III). A possible explanation for the superiority of SCA is that the cultivars/lines studied were selected by previous assays. There are indications that, by adopting this procedure, the genetic variance for additive effects (GCA) is reduced, increasing the relative importance of the non-additive genetic effects (Sprague and Tatum, 1942; Lonquist and Gardner, 1961; Allard, 1971; and Vencovsky, 1980). Using adapted and non-adapted common bean cultivars with a wide genetic variation, Abreu (1997) observed that, both for GCA and SCA, there were significant effects of similar magnitude.

According to Griffing (1956), parents which present the highest GCA estimates should generate a population with a higher mean yield. However, in the process of choosing parents, the highest GCA alone is not sufficient for this choice, since, if the parents are genetically similar, the population will present a restricted variability, reducing the chances to select improved lines. On the other hand, SCA measures the degree of allelic complementation. Therefore, a SCA with a higher and positive magnitude, as compared to GCA, indicates that there are crosses likely to liberate greater variability than others. Thus, the results of the
Table III - Variance analysis with decomposition of population effects in general and specific combining abilities, related to grain yield $(\mathrm{kg} / \mathrm{ha})$.

\begin{tabular}{lcc}
\hline Sources of variation & Degree of freedom & Mean square $\left(10^{-5}\right)^{\frac{1}{-}}$ \\
\hline Populations & 61 & $2.84^{* *}$ \\
GCA & 11 & $4.23^{*}$ \\
SCA & 50 & $2.53^{* *}$ \\
Error & 122 & 1.46 \\
\hline
\end{tabular}

$1 / *$ and $* *$ : significant at the $5 \%$ and $1 \%$ levels of probability, respectively, in the $\mathrm{F}$ test.

diallel regarding grain yield suggest that this cross scheme should be efficient in choosing the more promising segregating populations, that is, those with high SCA values, coming from parents with the highest magnitudes of GCA.

In ongoing breeding programs, previously selected superior lines and the best cultivars already in use are usually interbred (Fehr, 1987). However, the problem of this practice is the increasing degree of parentage among the superior parents used. The consequence of the crossing of these related parents is the generation of segregating populations with a reduced variability.

In the current study, the parents are from the Carioca group, all are represented by selected lines and cultivars used by the farms, with the exception of the Ouro Negro cultivar of black seeds. Thus it is possible that their degree of parentage is high. Consequently, this is the situation in which the choice of parents or of the more promising segregating populations should ensure a more successful program.

The estimates of general combining ability $\left(g_{i}\right)$ for each parental line/cultivar are found in Table IV. $\mathrm{g}_{\mathrm{i}}$ estimates close to zero indicate that the cultivar/line does not differ from the general mean of all crosses. On the other hand, positive or negative estimates indicate that the respective parent is better or worse than the other cultivars/lines included in the diallel, as compared to the mean yield of the crosses (Griffing, 1956; Vencovsky, 1969). Those values correspond to the frequency of favorable or unfavorable alleles of the parents with additive effects for grain yield. Consequently, parents with higher $g_{i}$ values should generate a segregating population with the highest mean yield, from which better lines can be selected.

The positive $\mathrm{g}_{\mathrm{i}}$ values presented by Aporé, PF-90975, CI128, Ouro Negro and Pérola indicate that they are ideal for the generation of populations with a high grain yield (Table IV). On the other hand, the ESAL 693 line showed the highest negative estimate of $g_{i}$, differing from the highest positive value by approximately 5.2 times the standard deviation of $g_{i}$. The low yield potential of this line was already expected, since it is the only line with type I growth habit, the others being type II or III (Table I).

Table IV also presents estimates of the specific combining ability $\left(\mathrm{s}_{\mathrm{ij}}\right)$ of the 62 populations. Low $\mathrm{s}_{\mathrm{ij}}$ values indicate that the respective populations exhibited the grain 
Table IV - Estimates of heterosis (\%), specific combining ability $\mathrm{s}_{\mathrm{ij}}$ (between parentheses, above the diagonal), mean grain yield (kg/ha) (below the diagonal), and general combining ability $\left(\mathrm{g}_{\mathrm{i}}\right)$.

\begin{tabular}{|c|c|c|c|c|c|c|c|c|c|c|c|c|}
\hline $\mathrm{C} / \mathrm{L}$ & 1 & 2 & 3 & 4 & 5 & 6 & 7 & 8 & 9 & 10 & 11 & 12 \\
\hline 1 & & $\begin{array}{c}0.11 \\
(-342.02)\end{array}$ & - & $\begin{array}{c}21.39 \\
(394.89)\end{array}$ & $\begin{array}{c}25.02 \\
(887.57)\end{array}$ & $\begin{array}{c}9.76 \\
(-141.98)\end{array}$ & - & $\begin{array}{c}-2.85 \\
(-345.60)\end{array}$ & $\begin{array}{c}-3.69 \\
(-31.02)\end{array}$ & $\begin{array}{c}4.90 \\
(-116.98)\end{array}$ & $\begin{array}{c}-7.35 \\
(-547.47)\end{array}$ & $\begin{array}{c}26.10 \\
(242.60)\end{array}$ \\
\hline 2 & $3299.16 b$ & & $\begin{array}{l}17.71 \\
(89,81)\end{array}$ & $\begin{array}{c}9.00 \\
(-81.51)\end{array}$ & $\begin{array}{c}-2.61 \\
(-83.60)\end{array}$ & $\begin{array}{c}28.79 \\
(296.23)\end{array}$ & $\begin{array}{c}3.50 \\
(220.99)\end{array}$ & $\begin{array}{c}-20.72 \\
(-870.56)\end{array}$ & $\begin{array}{c}-7.49 \\
(-120.10)\end{array}$ & $\begin{array}{c}\mathbf{5 7 . 8 1}^{2} \\
(1181.44)\end{array}$ & $\begin{array}{c}6.10 \\
(-102.64)\end{array}$ & $\begin{array}{c}14.41 \\
(-188.04)\end{array}$ \\
\hline 3 & - & $3289.73 a$ & & $\begin{array}{c}12.30 \\
(-43.86)\end{array}$ & $\begin{array}{c}5.39 \\
(93.70)\end{array}$ & $\begin{array}{c}9.15 \\
(-266.60)\end{array}$ & $\begin{array}{c}5.86 \\
(229.29)\end{array}$ & $\begin{array}{c}17.15 \\
(241.73)\end{array}$ & $\begin{array}{c}23.88 \\
(821.05)\end{array}$ & $\begin{array}{c}-2.57 \\
(-393.65)\end{array}$ & $\begin{array}{c}-24.44^{3} \\
(-1083.75)\end{array}$ & $\begin{array}{c}36.35 \\
(312.29)\end{array}$ \\
\hline 4 & $4237.96 a$ & $3166.67 b$ & $3357.96 a$ & & $\begin{array}{c}-7.14 \\
(-240.77)\end{array}$ & $\begin{array}{c}-6.57 \\
(-626.99)\end{array}$ & $\begin{array}{c}7.09 \\
(338.01)\end{array}$ & $\begin{array}{c}14.90 \\
(249.22)\end{array}$ & $\begin{array}{c}-0.78 \\
(83.67)\end{array}$ & $\begin{array}{c}-11.06 \\
(-562.49)\end{array}$ & $\begin{array}{c}42.22 \\
(1027.59)\end{array}$ & $\begin{array}{c}0.39 \\
(-537.77)\end{array}$ \\
\hline 5 & $4504.20 \mathrm{a}$ & $2938.15 b$ & $3269.08 b$ & $2982.86 b$ & & $\begin{array}{c}1.01 \\
(-79,06)\end{array}$ & $\begin{array}{c}-29.42 \\
(-544.34)\end{array}$ & $\begin{array}{c}1.76 \\
(159.11)\end{array}$ & $\begin{array}{c}-15.86 \\
(-101.20)\end{array}$ & $\begin{array}{c}-6.24 \\
(-101.59)\end{array}$ & $\begin{array}{c}5.06 \\
(214.25)\end{array}$ & $\begin{array}{c}0.21 \\
(-204.06)\end{array}$ \\
\hline 6 & $3448.81 \mathrm{a}$ & $3292.13 b$ & $2882.93 b$ & $2570.79 b$ & $2892.30 \mathrm{~b}$ & & $\begin{array}{c}2.27 \\
(76,80)\end{array}$ & $\begin{array}{c}8.73 \\
(-80.01)\end{array}$ & $\begin{array}{c}-8.26 \\
(-234.83)\end{array}$ & $\begin{array}{l}15.79 \\
(7.22)\end{array}$ & $\begin{array}{c}45.52 \\
(874.90)\end{array}$ & $\begin{array}{c}35.62 \\
(174.32)\end{array}$ \\
\hline 7 & - & $3164.42 b$ & $3326.34 b$ & $3483.32 \mathrm{a}$ & $2374.54 b$ & $2969.84 b$ & & $\begin{array}{c}16.60 \\
(787.18)\end{array}$ & $\begin{array}{c}-28.91 \\
(-445.63)\end{array}$ & $\begin{array}{c}-7.96 \\
(-34.24)\end{array}$ & $\begin{array}{c}-12.02 \\
(-223.13)\end{array}$ & $\begin{array}{c}-11.21 \\
(-404.93)\end{array}$ \\
\hline 8 & $3561.78 \mathrm{a}$ & $2441.93 b$ & $3707.86 a$ & $3763.61 \mathrm{a}$ & $3447.06 a$ & $3182.10 \mathrm{~b}$ & $3996.81 \mathrm{a}$ & & $\begin{array}{c}-21.36 \\
(-532.50)\end{array}$ & $\begin{array}{c}3.88 \\
(-43.46)\end{array}$ & $\begin{array}{c}20.68 \\
(503.64)\end{array}$ & $\begin{array}{c}13.06 \\
(-68.71)\end{array}$ \\
\hline 9 & $3601.81 \mathrm{a}$ & $2917.83 b$ & $4012.63 a$ & $3323.50 \mathrm{~b}$ & $2912.20 \mathrm{~b}$ & $2752.72 b$ & $2489.43 b$ & $2771.61 \mathrm{~b}$ & & - & $\begin{array}{c}-17.61 \\
(-420.42)\end{array}$ & $\begin{array}{c}36.93 \\
(981.02)\end{array}$ \\
\hline 10 & $3228.02 b$ & $3931.55 \mathrm{a}$ & $2510.10 \mathrm{~b}$ & $2389.51 b$ & $2623.97 b$ & $2706.94 b$ & $2613.00 \mathrm{~b}$ & $2972.86 b$ & - & & $\begin{array}{c}9.88 \\
(63.76)\end{array}$ & - \\
\hline 11 & $3247.11 \mathrm{~b}$ & $3097.05 b$ & $2269.57 \mathrm{~b}$ & $4429.16 a$ & $3389.40 \mathrm{a}$ & $4024.21 \mathrm{a}$ & $2873.69 \mathrm{~b}$ & $3969.54 \mathrm{a}$ & $2770.91 b$ & $2967.26 b$ & & $\begin{array}{c}6.73 \\
(-306.72)\end{array}$ \\
\hline 12 & $3831.92 \mathrm{a}$ & $2806.39 b$ & $3460.35 a$ & $2658.55 b$ & $2765.83 b$ & $3118.37 \mathrm{~b}$ & $2486.63 b$ & $3191.93 b$ & $3967.11 \mathrm{a}$ & - & $2841.11 \mathrm{~b}$ & \\
\hline $\mathbf{g}_{\mathrm{i}}$ & $525.48^{4}$ & -69.41 & 84.23 & 132.48 & -93.95 & -119.79 & -172.27 & 194.80 & -77.75 & $-365.58^{5}$ & 83.10 & -121.26 \\
\hline
\end{tabular}

1-: Means followed by the same letter in the column did not differ at the $10 \%$ level of probability in the Scott-Knott test.

C/L: cultivars/lines (1- Aporé, 2- H-4-7, 3- PF-9029975, 4- CI-128, 5- Carioca MG, 6- CI-21, 7- Carioca 300V, 8- Ouro Negro, 9- A-285 Rudá, 10 - ESAL 693, 11- Pérola, 12- IAC Carioca Aruã).

2l: $\mathrm{F}_{2}$ populations with highest heterosis and $\mathrm{SCA}$ values.

3/: $\mathrm{F}_{2}$ populations with lowest heterosis and SCA values.

4/ : cultivar with highest GCA value.

5/: line with lowest GCA value.

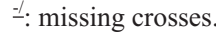

yield predicted by their parents' general combining abilities. However, positive or negative $\mathrm{s}_{\mathrm{ij}}$ values indicate that the grain yield of a particular cross is respectively better or worse than expected, based on the parental GCA (Griffing, 1956).

Out of the $\mathrm{F}_{2}$ populations deriving from parents with positive $\mathrm{g}_{\mathrm{i}}$ values, Aporé x CI-128, CI-128 x Pérola, PF-9029975 x Ouro Negro and CI-128 x Ouro Negro also exhibited positive $\mathrm{s}_{\mathrm{ij}}$ values and high grain yield, therefore being the most promising ones for line selection. It should stressed that the first two populations stand out not only for their higher yield, but also for having Carioca type grains, which significantly facilitates the selection of lines with a grain type that is well accepted by the consumers. It was also observed that the highest mean yields were presented by populations of which at least one of the parents showed positive GCA (Table IV).

It is important to mention that even within a group of non-adapted cultivars/lines there are some combinations that supplement themselves, such as H-4-7 x ESAL 693,
285 Rudá x IAC Carioca Aruã, and PF-9029975 x IAC Carioca Aruã. They displayed grain yield, $\mathrm{s}_{\mathrm{ij}}$ and heterosis of great magnitudes (Table IV), although the general combining abilities of their parents were negative, except for line PF-9029975. It is worth pointing out, however, that there is a possibility of grain yield variability liberation in these populations, which can be exploited for the selection of superior lines.

Heterosis $\left(\mathrm{h}_{\mathrm{ij}}\right)$ estimates (Table IV), were coherent with the SCA estimates, i.e., hybrid combinations with high SCA values presented high values of heterosis, as indicated by the rank correlation between those variables $(r=$ $\left.0.71^{* *}\right)$. This association suggests that heterosis can be used for the choice of potentially more segregating populations in situations where SCA cannot be estimated.

\section{Conclusions}

1. Differences in grain yield of the $F_{2}$ populations could be mainly explained by specific combining ability, 
which constitutes an efficient predictor of population variability;

2. Among populations derived from parents with positive $\mathrm{g}_{\mathrm{i}}$ values, Aporé x CI-128, CI-128 x Pérola, PF-9029975 x Ouro Negro, and CI-128 x Ouro Negro also exhibited positive $\mathrm{s}_{\mathrm{ij}}$ values and high grain yields, therefore being the most promising ones for the selection of lines.

3. The significant positive correlation between SCA and heterosis indicates that both estimates are useful to predict potentially more segregating populations.

\section{Acknowledgments}

Research supported by CNPq and FAPEMIG.

\section{References}

Abreu A de FB (1997) Predição do potencial genético de populações segregantes do feijoeiro utilizando genitores interraciais. Doctoral thesis, Universidade Federal de Lavras, Lavras, MG.

Allard RW (1971) Princípios de melhoramento genético das plantas. Editora Edgard Blucher, São Paulo. pp 381.

Cruz CD and Vencovsky, R (1989) Comparação de alguns métodos de análise dialélica. Revista Brasileira de Genética 12:425-438.

Falconer DS (1987) Introdução à genética quantitativa. Viçosa: UFV, Imprensa Universitária, pp 279.
Fehr WR (1987) Principles of cultivar development. New York: MacMillan. pp 536.

Griffing JB (1956) Concept of general and specific combining ability in relation to diallel systems. Australian Journal of Biological Science 9:463-493.

Lonquist JH and Gardner CO (1961). Heterosis in inter-varietal crosses in maize and its implication in breeding procedure. Crop Science 1:179-183.

Ramalho MAP, Santos JB dos, and Zimmermann MJO (1993) Genética quantitativa em plantas autógamas: aplicações no melhoramento do feijoeiro, Goiânia: UFV, pp 271.

Searle SR (1976). Linear models for unbalanced data. New York: Wiley, pp 536.

Sprague GF, and Tatum LA (1942) General vs specific combining ability in single crosses of corn. Journal American Society Agronomy 34:923-932.

Veiga RD, Nunes GHS, and Santos JB dos. (1998) Associação de parâmetros do dialelo com a variabilidade de populações segregantes avaliada por simulação. In: Encontro Mineiro de Geneticistas 5, Sociedade Brasileira de Genética Regional Minas Gerais, Viçosa, pp 65.

Vencovsky R (1969) Genética quantitativa. In: Kerr WE (org.) Melhoramento e genética. São Paulo: Melhoramento, pp17-38.

Vencovsky R (1980) Herança quantitativa. In: Paterniani E e Veigas, G. Melhoramento e produção de milho no Brasil. 2.ed. Campinas: Fundação Cargill, ESALQ, Piracicaba, pp122-199.

Vencovsky R and Barriga P (1992) Genética biométrica no fitomelhoramento. Ribeirão Preto: Sociedade Brasileira de Genética, pp 486. 